\title{
DEBATE ON 'INTERNATIONALIZATION' AND 'QUALITY' IN HIGHER EDUCATION OF POST-COLONIAL INDIA: A CRITICAL ANALYSIS
}

\begin{abstract}
Kumar Anand
If there is any cardinal point in education at any level that touches huge chord across board, it is 'quality' and 'reform'. The combination, perhaps, brings a whole set of questions from ideal to practices, roles of educational institutions, the nature of state, absorption in labour market, etc. Keeping such linguistic cliché, the higher education of India has moved to allow greater space for private sectors as well as internationalisation that is exemplified in twelfth five year plan report (2012-2017). However, it raises perplexing question of whether policy prescriptions alter institutional orientation of education system or other way around. Rather than trailing against this issue, this paper is woven around the 'quality' issue that leads to reform. Within it, international dimension sometimes converge (or diverge) in and around higher education institution. Rather than try to critically examine the enunciation of the concept 'quality' which presupposes 'reform' in the debate of higher education, and traces the context in which this concept emerged at specific juncture which has its continuity in contemporary era, it argues that 'quality' is shaped and nurtured by the international dimension even though there is sheer amount of ambiguity prevailing over these terms. The paper is drawn on fragmented scholarly literatures, reports and an attempt is made to delineate with examples.
\end{abstract}

Keywords: Internationalisation, quality, privatisation and state.

\section{Introduction}

The higher education system in India seems to be caught in somehow a peculiar trajectory of change (or reform). On the matter of the changes underway, the Twelfth Five Year Plan (2013) made a clear objective by brining 'internationalization' to the core. Globalization or internationalization of higher education is said to be offset of neoliberal doctrine that has pushed for eliminating trade barrier and easing the free movement of goods and services (Sidhu 2006). Even though modern education is known to be universal in function, for example, with respect to knowledge production, knowledge dissemination, examination, orientation in different disciplines, etc., that stems from modern science and ultimate integration and interaction. Indeed, these are lynchpin of education. In fact, the interaction between different knowledge system amid diverse sociohistorical context through education and knowledge has long been recognized (Sen 2005). In fact, the ambiguities over the term 'internationality' appear when it comes to contrasting with nation-state, if modern education is about 'universalism', particularly in 
countries where such education is established under auspicious of colonizer. And if its existence is undeniable, one might turn up to what has been its ramification on 'quality'. Perhaps, if this clarity is brought into notice, one would better demarcate between national and international. To put it somewhat differently, the nuance configuration of description would complicate the matter of higher education whereby the interplay of internationalization and quality becomes indispensable.

The sheer negligence of higher education has been observed in recent decades and there is growing attention among scholars about higher education in India (e.g., Kapur and Mehta 2004; Jayaram 2004; Beteille 2010) that is grounded with diverse vantage point. However, there seems to be an agreement on the point of 'quality' - it has been eroded over period of time as expansion could not sustain it - let put pressure on this assessment and tease out as to see in which way the quality is linked with internationalisation, if at all. Wittingly, the quality has become the lowest point of higher education in which demand for 'reforms' is expounded. Thus, one diagnosis is often offered to 'internationalise' and 'privatise' institutions, or its certification to halt this trend.

The growing attraction of 'internationalisation' is most visible in recent Wadhwa and Jha's study (2014) who see its manifestation in terms of collaboration of research (or institution) and opening up institution in developing countries apart from mobility of teachers and students. Their main thesis lies in the massive gain generated by developed countries in terms of attracting students from developing countries (see also Sidhu 2006). If one takes students' mobility as a central point of internationalization, the increase seems to be minor. Indeed, according to UNESCO (2015: 34) somewhat 8 million students were international in 1975; their number increased up to 1.7 million in 1995 and sharply rose up to 4.1 million in 2013. Needless to say, the sharp increase of international students between 1995 and 2013 depended on several factors: the first is, obviously, the increase in number of students in developing countries from Africa to Asia, and second, is the prevailing situation in certain countries or regions, for example, the on-going conflict in Arab world. Besides, the UNESCO (2015) report shows that the student's mobility has not always been from developing to developed countries, rather there is observed a substantial increase of the number of students moving from one country to other within region. However, what is important to note is that student mobility existed even before the rise of neo-liberalism. So what can explain this?

The answer lies in the catch of the developing countries like India's higher education institutional innovation and its effect on shaping issues of quality since postindependence. Hence, there is a tendency to rely heavily upon student mobility in internationalize arena and to pay far too little attention to other factors, as is indicated earlier, in era of globalization. And, this line of argument somewhat overestimates the reach and depth of internationalization of the Indian higher education. Contrary to this line of reasoning, we rely on the historical analysis which shows that higher education in countries like India has been expended after independence along the line of international dimension as well. Thus, as paper contends, a number of reform initiatives have been carried out which has international dimension, even before the rise of neo-liberalism in post-1990s India. Thus, inherited institutional structure from British colony and subsequent reforms after independence have visible ramification on wider educational institutions and practises of which 'international dimension' is hard to distinguish. As a con- 
sequence, the issue of 'quality' - what does mean by this term and whether it would be possible to demarcate between 'quality' and 'international' - in higher education of India became constitutive as well as regulative principle.

First, it is noteworthy to remind that language within any educational discourse plays a significant role. A lot is at stake in how issue of language in educational discourse is responded. The extreme consequences of the failure to address these challenges adequately are well known: continuity. In the context of language, India's response has been, historically, continuum yet distinctive feature added after independence. Thus, the continuity is observed when English as language of education continues to provide windows of opportunity, in term of career, even after independence. Otherwise, English language could have been done away since many leaders, most notably Gandhi, aspired to bring SWARAJ(meaning self-rule that encompass education in the language of mother tongue as Gandhi envisaged) or Azad - a freedom fighter and first minister of education in independent India who held similar view of Gandhi (Habib 2010: 20). As matter of fact, the presence of English language in education of India still attract critics like Priyadarshini (2010) who terms English as hegemonic (p. 85) whereas proponent argues English to be generating opportunities (Azam, Chin, and Prakash 2013). Notice, while the former set of proposition is inferred from elementary that stretching up to higher education while latter is English as a kind of skill that are in demand. Undoubtedly the presence of English is undeniable even after more than six decades of independence In general, English somehow shapes the contours of quality especially in the case of higher education unlike the vernacular, but the question is whether language alone covers the whole trajectory of quality. Most plausible reasoning would provide negative response. Nonetheless, it gives clue about how contention and compromise has been waged since colonial advent of education system that permeates from elementary to higher education.

\section{Theoretical Framework}

With respect to education, the 'quality' presents an unprecedented level of ambiguity. On the one hand, the assessment of the quality of education depends on who is measuring (or judging) it. It might be perfectly possible that an employer in labour market would conceive degree and acquired knowledge differently from, say an academician or a job seeker (Sanyal 1987). Thus, there is a perpetual conflict over considering the relation between education and 'quality' in different spheres, not to say in the job market. On the other hand, some scholar equates resource (i.e., funding) availability as input corresponds to output (i.e. research paper publication) (Tilak 1993). In this line of reasoning, assessing the 'quality' of education becomes difficult in historical context as resource constraint has been often discussed theme of elementary to higher education since colonial time (Tilak 1993; Kumar 1998). Nonetheless, it opens the question of seeking variation among different kind of institutions at different level. In fact, Naik (1979) observes that there is lack of clarity over 'quality' that stems from taking either input or output as sole criterion. On the other hand, the 'internationalisation' of higher education is articulated in terms of mobility of students, faculty as well as collaboration that might be in nature of joint curricula among institutions or joint research (Altbach 2009; Harris 2011; Deshpande 2012; Wadhwa and Jha 2014). Thus, to think of univer- 
sities structured under nation-state would either of two contested perspectives or combination of both views.

Either way, the centrality of nation-state in structuring higher education becomes inevitable. Herein the infusion of international dimension in higher education complicates picture in countries like India where the division between central and state institution as a result of federal structure of constitution and politics has been burgeoning over period of time. While the former would interact with international dimension in term of students and researchers mobility, later institutions have been confined to cater student at the state level.

Broadly, the input-based quality relies on the resources, teachers-students ratios and so on, while the output-oriented understanding relies upon the acquired skills and knowledge. If the latter proposition is taken in full account a great part of higher education, especially universities and colleges, come under difficulties of demand and supply mismatch due to the incoordination between what is requirement at present time in job market and what is taught (Sanyal 1987). Moreover, whether educational institutions, especially universities, have any coordination mechanism is very doubtful. However, the 'quality' of education is said to be a complex interplay of both (input and output) in which internationalisation - broadly transcending national-state boundary through mobility of students and faculties as well as collaboration and exchange programme has been playing a crucial role in shaping up institutions in India.

With this background, the present paper is arranged into three parts starting with the briefly described historical background of higher education in Europe and turning up to the establishment of modern education in India. The next section deals with the complex differences between mass-elite institutions within the nation-state. Meanwhile, it sheds light on the post-independence wherein a fair amount of 'internationality' was infused on different constituents of education (i.e., curricula, or institutional formats) and its governing model that has been sustained for more than six decades. Above all, this paper, largely, concerns with higher education expansion from 1947 to 1990 even before the neo-liberal economic policies were set in place thereby underscoring the complexity that manifests.

\section{Emergence of Higher Education}

The main centre of higher education and learning in India goes back to the Nalanda University which attracted scholars from different countries like China, as Sen (2005) observed. Although ancient centres for learning whether higher education institutions like Nalanda University nearby modern Patna (Bihar) or Cambridge started in medieval period in England, they mainly stood for the search for truth and knowledge and were patronized by prevailing religion of that time (Beteille 2010). And yet their presence was few in number. Harris (2011) acknowledges that even in the European countries one can hardly trace the root of universities to far back except for few like Oxford, or Cambridge and Glasgow in UK, and very few in Spain or Germany, or France (Harris 2011: 20).

In fact the period of Renaissance casted European history to undergo many changes but most important is the religious reform through protestant ethics. Weber (2001 [1930]) has argued that the emergence of modern capitalism was accompanied by reli- 
gious reform: for instance, Luther, the major figure of the Protestant reform (cited in Geoge 2010: 75) claimed that everyone should be literate in order to read sacred scripture and subsequently, gain the enormous wisdom residing in text. Also modern invention like printing and so on fuelled up the process in which Asian countries, namely China and India, played crucial role. Subsequently, the first printed book appeared in China and it was the book of Indian treaties - the Diamond-Sutra - on Buddhism, as Sen (2005: 183-184) observed. In the sense, these changes have had far reaching consequences upon what is often called a modern society.

Thus, the industrial revolution as well as formation of nation-state brought about an unprecedented level of bureaucratisation when education got closely tied with division of labour. In fact, Olson (2003) traced the earliest connection between education and occupation by quoting Grendler in 1333 commune of Chioggia decreed that judge and civic official must read and write to hold their jobs, since secular social roles such as judge or administration required special training that was to be provided by newly established universities (Grendler 1989: 168).

On the one hand, specialized higher education was introduced in Germany in the $1820 \mathrm{~s}$ and it was to train youth for emerging industrialization. Consequently, that region became one of the highly technological advanced areas due to absorbing of educated people (Chang 2002). On the other hand, Humboldt - the minister of education and worship - introduced a model of university but regained from ministerial post few month earlier of inauguration of Berlin university in which teaching and research to be reciprocal thereby nation-state development could take place (Gerbod 2004; Beteille 2010). Historically, it is still disputed whether German universities really became the centres of research or not in the response of Humboldt vision, and to what extent if it was the case (Ruegg 2004: 12). Nevertheless, it sets stage for certain level of departure of the very idea of universities from erstwhile one, and attracts enormous attention as pursuit (Beteille 2000).

Anyway, this was coincided with the establishment of Frederick II's regime in Prussia (now Germany) in the nineteenth century wherein the selection for bureaucracy had to be made from modern higher education system (Perkin 1996). Hence, the career (or occupation) via education had been one of the major points of departure from earlier education that could be observed in the case of Germany, or other countries even though the institutional arrangements of these countries vary substantially from each other (Perkin 1996; see also Weber 2005).

Similarly, Napoléon established institutions of higher learning with specialization in particular fields, for example, engineering, or military training, which would be available for gifted students who were taken from rigorous examination that led to the selection on basis of merit (Perkin 1996; Beteille 2010). On the other hand, universities of France no longer remained only teaching - learning institutions but were engaged in research activities even though it was taken to be secondary in the government's priority list and were under central control (Ruegg 2004). On the whole, the differences as well as little similarity among the European countries with respect to higher education of learning could be observed which stems from the vision as well as practices.

The combination of research and teaching makes the modern higher education distinct from former institutions whereby the frontier of knowledge bound to be pushed up 
(or pull down). For instance, Beteille (2010) points out that the more secular (or scientific) kind of education emerges out of these changes which could be recognized by simple fact that 'theology'(a broader discipline of religion) was side-lined in modern university and no longer constituted its main subject matters.

\section{Institutional Frame of Higher Education in India}

The modern universities of India were established by the British in 1857 to prepare Indians to be part of administration and were devoid of religious affiliation (Beteille 2010; Calhoun 2011). The British model of university was replicated in India whereby the university had to concern with examination and conferring degree while actual classes of teaching and learning took place in affiliated colleges (Singh 2006). In this model, the research was absent from all three universities established by the British, namely: Calcutta, Bombay, and Madras. In fact, it was during the early twentieth century under Act of Universities (1904) established universities were empowered to reorient in direction of research along with teaching-learning (Ghosh 2009). On the other hand, the second model of universities was also introduced in which teaching-learning would combine with research, one can find this tradition in the establishment of Banaras Hindu University or other universities of the early twentieth century in which remodelling was performed.

After Independence, committee on higher education introduced the establishment of IITs, or Indian Institutes of Management (IIMs), the latter being specialized in discipline, e.g. engineering, or medical (as Napoleon started in France). Hence, the import of 'institutions' continues even after post-independence period so the agricultural universities or IITs have been adopted from the USA (for IITs see Indirsen 2000). Similar is the case of Indian Institutes of Management (or IIMs) - it is by now considered as elite institution in India- which was established and nurtured with the help of Harvard University. It is interesting to note that the introduction of management as a discipline started with Harvard University in 1908 (Allison 2006: 66) and was adopted (or adapted) across the globe. Thus, what is worthwhile to notice that higher education in India can be broadly characterized by three different organizational form: 1) specialized kind of educational institution, 2) university as a unitary model where teaching-learning and research are combined, and 3) university operating through affiliation with college that was set up in colonial time.

Soon after independence attention was paid to higher education as the Report of the University Education Commission - well known as Radhakrishnan Commission (1950) - dwelled at length on the road map for expansion- in terms of more colleges and universities that could enable students to pursue higher education. Here also one would find an ample reference to diverse institutional models as well as to disciplines that were taken from other countries; starting, for instance, from agricultural universities of the USA and to universities from other countries like Danish college of agriculture (pp. 672-681). In rural university it was envisaged that the core of learning and research would respond to different needs of rural areas ranging from administrative training to engineering (Radhkrishnan commission 1950: 682-687). As matter of our interest, contrary to Radhakrishnan commission proposal, in the 1960s India brought the American model of agricultural universities thereby minimizing the role of University 
Grant Commission (henceforth UGC) in the formation of institution (Abrol 2010). This can be inferred as a form of trans-nationalisation which resulted from interaction with institutions but shaped by the necessities of day rather by the policies reflection. Thus, it does illustrate the persistence of 'internationality' angle in the case of India.

\section{Mass-Elite Institutions}

In the twentieth century one of the main changes in higher education was its expansion which is identified as the major reason for growing scholarly engagement (Brennan and Teichler 2008) in which the distinction between mass and elite becomes inevitable. However, it is equally important to note that this expansion was identical with the British model. As a matter of fact, according to Twelfth Plan (2013), 86.7 per cent of all students got enrolment in the affiliated colleges of universities that fall under state. Further, these colleges enrol over 90 per cent of undergraduate students, over 70 per cent of the post-graduates and about 17 per cent of doctoral students thereby following curricula and examination systems determined by the affiliated universities (see Ministry of Human Resources 2013: 95). Thus, universities of state in the federal system tended to play larger role at the level of graduation and post-graduation level.

It is also the case an overwhelming number of institutions still have affiliation system. For instance, the Calcutta University - one of the oldest university of India - has more than two hundred colleges (Altbach 2009). One of unintended consequence here is the immense tension in smooth functioning (Beteille 2010), and some scholars think the distance(in term of governance ) between university and college are major causes of floating norms, low quality of education and so on (Singh 2006). Also, this proves the failure of reports and recommendation to reform as well as of suggested structural change of such universities (Altbach 2009). The thing is that the expansion has been made without any kind of reform of previous mechanism that was inherited from colonial time. These challenges are propounded by the difficulties faced by the Indian federal structure in keeping check and balance over higher education system as matter a fact that centre-state relation has undergone drastic changes in post-independent India (Carnoy and Dossani 2013). As early as in the 1960s, Gaudino (1965) observed that many universities are opened despite the lack of facilities to manage them. In this line of argumentation, the 'quality' is broadly interpreted as a matter of regulation and governance and in this case even a minimum level of education in terms of inputs, e.g. teaching quality, relevance of curricula and assessments can be met or maybe, not.

Such legacy continues to exist or has been intensified in the period after Gaudino (1965) or Naik (1979) writings. Similarly, Jayaram (2004) writes that more than 80 per cent of students study in state universities, but these universities have not changed on the frontier of teaching-learning (or improvement in quality and in fact there are cases of degree without imparting any sort of knowledge). Indeed, it has been recognized since independence that there is an emerging bureaucracy among academia who has majority to say in any decision and want to carry the orchestra in order to get appreciation without reflecting on show (e.g., see Desai et al. 1960 observations on this issue). Hence, there seems to be agreement over the fact that present structure as well as function of higher education suffers from unprecedented level of irrelevance in content as well as resource constraint from almost all major inputs amid massification. What does it crucial- 
ly miss is the lack of clarity on whether the resources requirements are met or not. If for all institutions the scarcity of resources has been the cause of impediment, then analytically it would be plausible to infer 'quality' of education is almost stagnated.

Herein Naik's distinction seems reasonable whereby mass and elite education system works in the consequence of expansion and creates this distinction itself. Naik (1979) writes that the distinction between mass education and elite is quite visible, while the former is damaged with sheer politics, lack of resources, low motivation in teaching-learning process; whereas the elite institutions attract more resources and best talents.

Given such messy expansion that has taken place since independence, there is a difficulty in mass-elite distinction. In this respect, there are broadly two different conceptual schemas: the first conception of mass higher education allows over 15 per cent of the young to have access to higher education Bai (2006). If this definition is literally taken, India can manage to cross that threshold. Yet, it would be hard to conceive the massification meaning the absence of hierarchies among different institutions (Naik 1979). Second, Beteille's (2010) definition of mass education rests on Shils's conception in which more than twenty thousand student study under single higher education institution, for example, college or university. Of course, Shils's definition is driven by the USA experience, but the size and number of students have grown rapidly since the postindependence period in India, too (Beteille 2010: 169). Thus, the Delhi University, for instance, could be counted as an establishment of mass higher education, as Beteille (2010) seems to be suggesting. Nevertheless, the distinction between mass and elite higher education is contested on the ground of defining features in India. Yet, only the intake capacity of any institution deliberately rules out the possibility of other criterion like resources, mobility through exchanges and other means, as well as its output.

On the other hand, Jayaram (2004) distinguishes between mass-elite on the basis of centre and state higher education institution of India in which states have large strength of students. Yet, state's educational institution could not sustain the credibility to improve quality even though the UGC has intervened in the process from time to time. Thus, the private players eagerly fill the vacuum in which many are able to meet the demand of opportunities generated by market and some are just mushrooming to generate profit without imparting any sort of skill. However, the problem with such arguments lies in two dimensions: 1) if states have taken the leading role in providing higher education how could they not try to regulate it according to their own needs given the obvious fact that education is listed in concurrent list of the constitution. In consequence, there bound to be tussle over who would regulate, as pot-independent India's expansion seems to be suggesting (Carnoy and Dossani 2013). 2) Uniform measure is highly improbable due the disparity of state over educational discourse that are closely tied with state revenues and (in) ability to fund education. Overall, the higher education in India has been marred and oscillated by the problem of its control and the issue of financial support of the expansion. Nonetheless, a vast majority of affiliation colleges under state's universities lack research activity as well as having no 'international' dimension, even though some disciplines, for example, management, might be diffused from above. 


\section{Privatisation and Internationalisation}

The cult of 'globalization' has galvanised education in recent decade by brining education under service sectors thereby it eased the cross-boundary regulation to free flow of capital and human power in search of better education. For instance, Sharma (2010) rests his argument on the move by the state to reform education in which the facilitation of trade (or creating market for international business in education) is pushed upon; thus privatisation and FDI investments are the core of such business that is backed by international agencies like WTO and World Bank (Sharma 2010). Yet, such consideration is tended to be canonized by a single most important fact that the existence of private institutions are neither new one nor the 'internationalisation', if the latter is taken in earlier defined conception. Or put it differently, seeds of international dimension has been infused in higher education of India.

Historically, the growing demands of higher education since the late 1970s have been often met by privatized institutions and by the turn of the twenty first century de facto privatized (Kapur and Mehta 2004). For instance, Twelfth Plan (2013) estimates that Central institutions should account for 2.6 per cent of the total enrolment; the State institutions should account for 38.5 per cent of enrolment; while the private institutions care for the remaining students (p. 90). Further, Twelfth Plan suggests that Growth in private institutions was significant during the Eleventh Plan period. Ninety-eight private State universities, 17 private deemed universities, 7,818 private colleges, and 3,581 private diploma institutions were set up during the Plan period. While a majority of them offer professional or vocational programmes almost exclusively, it is worth noting that a number of arts, commerce and science colleges and a few comprehensive multidisciplinary universities have also been established in the private sector in recent years (p. 95).

On the issue of privatisation, John and Nair (2011) observe that Supreme Court has ruled out consideration of education as mere business, but subsequent report reserves such constitutional ruling that is partially reflected in one judgment where Supreme Court observes business in education as 'unholy ring' (Kapoor and Mehta 2004).Yet, the penetration of unholy ring has been on the rise. In support of such move scholars like Menon (2011) argue that since higher education is not a matter of constitution guarantee, the problem of quality - which is widespread in government institutions should be overcome with privatized educational set up. On the overall expansion of higher education institution, some scholars' view this as paving the way to undermine democratic and secular ethos of education. Baxi (2011) writes that higher education does not fall under constitutional claim, so the Supreme Court has already (long before India became signatory of GATTs) cleared for profit motive of education and would serve the purpose of global capitalism.

However, there seems to be no constitutional clarity among scholars over whether higher education could be business or not, yet the education as a profit motive has started earlier in state like Karnataka, or Andhra Pradesh (Kaul 2000). In fact, the privatized expansion proves Kapur and Mehta (2004) argument that higher education of India is de facto massively privatized in spite of sheer rhetoric of socialism and ambivalent gesture of state apparatus, mainly regulatory regime as well as law on education. 
Since the private institutions have been growing rapidly in recent years they have started to take the path of collaboration and exchange. For instance, UK's London Schools of Economics and political science has, according to Suneja (2013), collaborated with the Chennai Based City School of Social and Managerial Sciences. Similarly, the UK based Warwick University has come together with Gurgaon's based ITM to offer engineering courses. So, it is safe to say that internal privatisation safely meets with growing attraction of international privatisation and cross-border engagement through mobility, or establishing institutions.

To be precise, internal (or more accurately within India) privatised higher education with growing share of 'internationalisation' is channelized through exchanges (or collaboration) programmes in different disciplines as Deshpande (2012) observes. Yet, the post-independent higher education in India has had those programme, i.e. exchange of students, as Desai et al. (1960) observed, although one might dispute over the precise number of mobility of students from India to other countries, e.g., UK. Also, which ways it does radically differ from on-going consideration, and what kind of changes it has brought in the journey of post-independence expansion.

It is rather easy to see and safer to say that linkages are, as is demonstrated above, maintained at the top level (or elite institutions) as in the case of IITs or IIMs, or at some universities (or college) through mobility. In this sense, Altbach rightly points that those who are trained and educated in Western countries often sit on the top of the ladder in institutional hierarchies of developing countries; in fact they are called 'power elite' of academic community (Altbach 2011: 210). Hence these things give a distinctive characteristics of 'quality' with international dimension in discourse of Indian higher education amid of massification which often tended to be canvassed in the socalled 'resources constraint'.

\section{Conclusion}

The appeal of 'internationalisation' has, undoubtedly, been gaining ground in policies formulation in recent years, yet it is hard to establish, especially in post-colonial countries like India, that grain of 'international' dimension was not there earlier. Needless to say, the emergence of modern higher education is accompanied by the rise of careerism (occupation) in Europe that were part and parcel of emerging nation-state and industrial revolution in which secular (precisely the absence of religious scripture at core of education) and scientific outlook of education permeated. It is in this sense modern education substantially departed from the formerly existing one. There is little doubt that the post-independent India has fused international dimension in higher education (i.e., an institutional model, disciplines), but also complicated distinction (or similarity) that might steam from language, or kind of institution, or disciplines. In addition, these elements also went into (re-)defining of 'quality' of higher education in India. Anyway, the affiliated colleges under university education was introduced in colonial time that still carry different courses on the large scale and has been overwhelmed by huge number of students. Similarly the unitary model of university (or specialised institutions like Agricultural, IITs, or IIMs) arose out of interaction of USA and India. However, the expansion of higher education have had made wider accessibility on the basis of different kind of institutions, mostly by undermining regulatory framework amid of resource 
constraint. Also, it does suggest limit of analysis merely based upon student mobility without looking at nitty-gritty of research as well as 'invented' disciples that has been infused with international angle. Perhaps, it indicates that one has to hedge own bet into the criss-cross of educational institution with enormous variation that ranges from language, disciplines, and interaction with other institution across boarder.

The 'internationalisation' term is widely used in form of exchange and mobility of student (or researchers) and now having wider appeal yet it existence earlier is undeniable. The puzzle is which ways it shapes the 'quality' amid of exchange, or taking stocks of teaching, or curricula, or studies from other countries. It is safe to say educated and trained through exchange (or precisely international institutions) or interlinked institution injection has led to the redefinition of 'quality'. Undoubtedly, these factors have made the conception of 'quality' more elusive.

\section{REFERENCES}

Abrol, D. 2010. Governance of Indian Higher Education: An Alternate Proposal. Social Scientist 38 (9/12): 143-177.

Allison, G. 2006. Emergence of Schools of Public Policy: Reflections by a Founding Dean. In Moran, M., Rein M., and Goodin, R. E. (eds.), The Oxford Handbook of Public Policy (pp. 58-80). New York, USA: Oxford university press.

Altbach, P. G. 2009. One-Third of the Globe: The Future of Higher Education in China and India. Prospects 39: 11-31.

Altbach, P. G. 2011. The Academic Profession: The Realities of Developing Countries. In Altabch, P. G. (ed.), Leadership for World Class Universities: Challenges for Developing Countries (pp. 205-223). India: Routledge.

Azam, M., Chin, A., and Prakash, N. 2013. The Returns to English-Language Skills in India, Economic Development and Cultural Change 61 (2): 335-367.

Bai, L. 2006. Graduate Unemployment: Dilemmas and Challenges in China's Move to Mass Higher Education. The China Quarterly 185: 128-144.

Baxi, U. 2011. Curricular Development and Value Education: A Tentative Outline. In Panikkar, K. N., and Nair, M. B. (eds.), Emerging Trends in Higher Education in India: Concepts and Practices (pp. 143-155). New Delhi, India: Dorling Kindersley Pvt. Ltd.

Beteille, A. 2000. Teaching and Research. Seminar, November, No. 495.

Beteille, A. 2010. Universities at Crossroads. New Delhi, India: Oxford University Press.

Brennan, J., and Teichler, U. 2008. The Future of Higher Education and of Higher Education Research: Higher Education Looking Forward: An Introduction. Higher Education 56(3): 259-264.

Calhoun, C. 2011. The Pubic Mission of the Research University. In Diana, R., and Calhoun, C. (eds.), Knowledge Matters: The Pubic Mission of the Research University (pp. 1-33). USA: Columbia University Press.

Carnoy, M., and Dossani, R. 2013. Goals and Governance of Higher Education in India. High Education 65: 595-612.

Chang, H. J. 2002. Kicking away Ladder: Development Strategy in Historical Perspective. UK: Anthem press. 
Das, S. 2007. The Higher Education in India and the Challenge of Globalisation. Social Scientist 35 (3/4): 47-67.

Deshapnde, S. 2012. Social Justice and Higher Education in India today Markets, States, Ideologies and Inequalities in a Fluid Context. In Hasan, Z., and Nussbaum, M. C. (eds.), Equalizing Access: Affirmative Action in Higher Education in India, United State, and South Africa (pp. 212-238). New Delhi, India: Oxford University Press.

Desai, I. P., Kothari, R. F., and Gulati, I. S. 1960. Our Universities. Seminar, March, 10-13.

Gaudino, P. L. 1965. The Indian University. Bombay, India: Popular publication.

George, V. 2010. Major Thinkers in Welfare: Contemporary Issues in Historical Perspective. UK: Polity press.

Ghosh, S. C. 2009. The History of Education in Modern India 1757-2007. New Delhi, India: Blackswan.

Gurbond, P. 2004. Relations with Authority. In Ruegg, W. (ed.), A History of the University in Europe, Vol. 3 Universities in the nineteenth and Twentieth Centuries 1800-1945 (pp. 83-100). UK: Cambridge university press.

Habib, S. I. 2010. Maulana Abul Kalam Azad on Education and Culture in Post Independent India. In Habib, S. I. (ed.), Maulana Abul Kalam Azad and the National Education System (pp. 15-31). New Delhi, India: NEUPA.

Harris, S. 2011. The Universities in Translation: Internationalizing Higher Education. London, UK: Continuum.

Indirsen, P. V. 2000. W(h)ither IITs? Seminar.

Jayaram, N. 2004. Higher Education in India: Massification and Change. In Altbach, P. G., and Umkoahi, T. (eds.), Asian Universities: Historical Perspectives and Contemporary Challenges (pp. 85-114). Baltimore, MD: Johns Hopkins University Press.

John, M. E., and Nair, J. 2011. Commission, reports and the difference they make. Seminar.

Kapur, D., and Mehta, P. B. 2004. Indian Higher Education Reform: From Half-Backed Socialism To Half Backed Capitalism. Centre for International Development, working paper No. 108, Harvard University.

Kaul, R. 2000. Wither equity? Seminar, No. 494.

Kumar, K. 1998. Education and Society in Post-Independent India: Looking towards future. Economic \& Political weekly XXXIII (23).

Ladha, K. A. 2012. Strategic Opportunities for Quality in Higher Education in India. IIM Kozhikode Society \& Management Review 1 (2): 65-7.

Ministry of Education. 1950. The Report of the University Education Commission. Vol. 1. New Delhi: Government of India.

Ministry of Human Resources. 2013. Annual Report 2012-2013. Department of School Education \& Literacy Department of Higher Education, New Delhi: Government of India.

Menon, M. M. 2011. Education for Democracy, Secularism and Inclusive Growth. In Pannikkar, K. N., and Nair, M. B. (eds.), Emerging Trends in Higher Education in India: Concepts and practices (pp. 60-66). New Delhi, India: Dorling Kindersley (India) Pvt. Ltd.

Naik, J. P. 1979. Equality, Quality and Quantity: The Elusive Triangle in Indian Education. International Review of Education 25 (2/3): 167-185. 
Neumann, R. 2009. Disciplinarily. In Tight, M., Mok, K. M., Huisman, J., and Morphew, C. C. (eds.), The Routledge International Handbook of Higher Education (pp. 487-500). New York, USA: Routledge.

Olson, D. R. 2003. Psychological Theory of Educational Reform: How School Remakes Mind and Society. New York, USA: Cambridge University Press.

Perkin, H. 1996. The Third Revolution: Professional Elites in the Modern World. London and New York: Rautledge.

Planning commission of India. 2013. Twelfth Five Year Plan (2012-2017): Social Sector, Vol. 3. New Delhi, India: Sage Publication.

Priyadarshini, M. 2010. Language Issues in Education. In Habib, S. I. (ed.), Maulana Abul Kalam Azad and the National Education System (pp. 79-90). New Delhi, India: NEUPA.

Ruegg, W. 2004. Theme. In Ruegg, W. (ed.), A History of the University in Europe. Vol. 3. Universities in the nineteenth and twentieth centuries 1800-1945 (pp. 3-32). UK: Cambridge University Press.

Sanyal, B. 1987. Higher Education and Employment: An International Comparative Analysis. London, UK: Flamer press.

Sen, A. 2005. The Argumentative Indians: Writings on Indian Culture, History and Identity. USA: Penguin.

Sharma, V. 2010. UPA's Agenda of Educational 'Reform' Facilitating Trade in Higher Education. Social Scientist 38 (12/17): 91-127.

Singh, A. 2006. Undergraduates verses Post Graduates. Economic \& Political, Weekly 41 (24): 2450-2454.

Sidhu, R. K. 2008. Universities and Globalization: To Market, To Market. USA: Lawerance Erlbaum Associates publication.

Suneja, K. 2013. World Class. The Financial Express, April 7: 7.

Tilak, J. B. G. 1993. Financing Higher Education in India: Principles, Practice, and Policy Issues. Higher Education 26 (1): 43-67.

UNESCO 2015. UNESCO Science Report: towards 2030. Paris: France.

Wadhwa, R., and Jha, S. 2014. Internationalisation of Higher Education: Implications for Policy Making. Higher Education for the future 1 (1): 99-119.

Weber, M. 2001 [1930]. Protestant Ethics and the Spirit of Capitalism. London \& New York: Routledge Classics.

Weber, M. 2005. Extract from Max Weber: Essays in Sociology. In Stehr, N., and Grundmann, R. (eds.), Knowledge: Critical Concepts, Knowledge And Economy Vol. 3. (pp. 151-162). UK: Routledge. 